Bangladesh J. Sci. Ind. Res. 42(4), 377-396, 2007

\title{
Physico-chemical and Biological Aspects of Monsoon Waters of AShulia for Economic and Aesthetic Applications: Preliminary Studies.
}

\author{
Md. Ariful Islam Khan, ${ }^{\mathrm{a}}$ A. M. M. Maruf Hossain, ${ }^{\mathrm{b}}$ M. E. Huda, ${ }^{\mathrm{a}}$ M. Shahidul Islam, ${ }^{\mathrm{c} *}$ \\ and Syed Fazle Elahi ${ }^{b}$ \\ ${ }^{a}$ Department of Environmental Sciences, Jahangirnagar University; ${ }^{\mathrm{b}}$ Department of Soil, \\ Water and Environment, University of Dhaka; 'Analytical Research Division, BCSIR \\ Laboratories, Dhaka, Bangladesh.
}

\begin{abstract}
In the north-eastern part of Dhaka the 'Turag River' extends over Ashulia thana with a few branches. The north-eastern part of Ashulia thana mainly constitute low lands with a physiography of Madhupur Tract interlaced with Brahmaputra Floodplain. Monsoon extends over these lands from May to October and from July to October these lands remain flooded with a water depth of more than $180 \mathrm{~cm}$ to less than 275 $\mathrm{cm}$ due to surface runoff of rain water and overflow of the river canals. The area under water during this four month period can be used for economic applications such as various types of fishery as well as enhancing the present recreational applications. For these purposes the physical, chemical, and biological aspects of the water are studied to evaluate its suitability for the applications. The study was held over the period of July through December, 2006, samples being taken once every month. The physical parameters covered transparency, odor, temperature, salinity, EC, TSS, and TDS. The chemical parameters of water studied were $\mathrm{pH}, \mathrm{DO}, \mathrm{BOD}_{5}$, COD, hardness, $\mathrm{NO}_{2}{ }^{---} \mathrm{N}, \mathrm{NO}_{3}{ }^{---} \mathrm{N}, \mathrm{PO}_{4}{ }^{3---}, \mathrm{SO}_{4}{ }^{2---S}, \mathrm{Cl}-, \mathrm{Na}, \mathrm{K}, \mathrm{Ca}, \mathrm{Fe}, \mathrm{Ni}, \mathrm{Cu}$, $\mathrm{Zn}, \mathrm{Cd}, \mathrm{Pb}$, and $\mathrm{Hg}$. Among the biological parameters 'phytoplankton' and 'zooplankton' were qualitatively identified in microscopic observation up to genera. From July to October the water was transparent and of good odor, temperature ranged from $28.2^{\mathrm{O}} \mathrm{C}$ to $24.6^{\mathrm{O}} \mathrm{C}$, salinity within 0.58 to $0.83 \mathrm{mg} / \mathrm{L}$, EC within 250 to $608 \mu$ mho/cm, TSS 0.42 to $0.82 \mathrm{mg} / \mathrm{L}$, and TDS within 2.8 to $5.2 \mathrm{mg} / \mathrm{L}$. Among the chemical parameters, $\mathrm{pH}$ ranged from 6.6 to 7.4, DO within 6.4 to $6.9 \mathrm{mg} / \mathrm{L}$, BOD5 within 1.5 to $3.28 \mathrm{mg} / \mathrm{L}$, COD within 3.04 to $12.89 \mathrm{mg} / \mathrm{L}$, hardness 26.08 to $37.5 \mathrm{mg} / \mathrm{L}$, $\mathrm{NO}_{2}--\mathrm{N}$ from undetectable to maximum $0.562 \mathrm{mg} / \mathrm{L}, \mathrm{NO}_{3}-\mathrm{-N}$ within 0.539 to 2.158 $\mathrm{mg} / \mathrm{L}, \mathrm{PO}_{4}{ }^{3}$--P 2.35 to $2.75 \mathrm{mg} / \mathrm{L}, \mathrm{SO}_{4}{ }^{2}-\mathrm{S} 0.23$ to $0.29 \mathrm{mg} / \mathrm{L}$, Cl- 1.65 to $6.16 \mathrm{mg} / \mathrm{L}$, Na 3.6 to $12.5 \mathrm{mg} / \mathrm{L}$, K 9.7 to $11.5 \mathrm{mg} / \mathrm{L}$, Ca 6.52 to $14.82 \mathrm{mg} / \mathrm{L}$, Fe 0.1269 to 0.5062 $\mathrm{mg} / \mathrm{L}$, Ni 0.028 to $0.050 \mu \mathrm{g} / \mathrm{L}$, Cu 0.028 to $0.043 \mathrm{mg} / \mathrm{L}$, Zn 0.023 to $0.048 \mu \mathrm{g} / \mathrm{L}$, Cd 0.0023 to $0.0043 \mu \mathrm{g} / \mathrm{L}, \mathrm{Pb} 0.043$ to $0.093 \mu \mathrm{g} / \mathrm{L}$, and $\mathrm{Hg}$ was not detected at ppb level. Among the biological parameters a number of phytoplankton were identified covering the classes of Bacillariophyceae, Chlorophyceae, Euglenophyceae, and Cyanophyceae. The zooplanktons included the orders Cladocera and Copepoda within the class Crustacea of phylum Arthropoda.
\end{abstract}

Key words: Freshwater ecology, Water resource management

*Corresponding author 


\section{Introduction}

In the north-eastern part of Dhaka the 'Turag River' extended with a few branches over Savar and Ashulia. These branches extend over the eastern part of Yearpur of Savar thana, and north-eastern part of Ashulia thana. The north and east of Ashulia mainly constitute low lands. Soils of these areas are of Madhupur Tract on which sediments deposit each year during monsoon flood. So the actual physiography constitutes Madhupur Tract interlaced with Brahmaputra Floodplain. Among the six climatic seasons of Bangladesh, three climatic seasons are mainly observed in these lands: the monsoon, winter, and summer. Monsoon extends from May to October, winter from November to February, and summer from March to April. So the longest climatic season observed in the lands is monsoon. Being low land the lands remain submerged for 6 to 7 months due to monsoon in a year with a water depth of more than $180 \mathrm{~cm}$ to less than 275 cm (Soil Resource Development Institute, 1992). Usually the lands remain submerged from June to November with varying depths of water. But for various applications these waters can better be used for four months - from July to October. Overflow through the river channels play an incremental effect to create continuous waters and also a definite relation exists with the river system in terms of water movement and fisheries.
As per the fourth decennial population census in the country, the enumerated total population is 123.1 million by January 22nd 2001 while the total area of the country is only 1,47,570 sq. Km (BBS, 2003). Day by day the agricultural lands as well as waters are being depleted for use up by housing, industrial, and infra-structural purposes. The fish habitats are decreasing with a potential threat on fisheries and fish resources to meet the domestic demand as well as export potential. Again the recreational aspect in the lives of people especially in the city areas is shrinking alarmingly which will carry an obvious deleterious effect on mental health. As with an appreciable depth these waters stay over as long a period as about four months as well as the existing relationship with river system through the river-channels, these waters can be managed for economic and aesthetic purposes rather than to be only the cause for misery. In this regard the waters must be evaluated for the physico-chemical and biological aspects in regard to fish production potentiality and human health for various economic and aesthetic applications. This study is aimed for preliminary exploration of the potentialities of the water for the above mentioned purposes.

\section{Materials and Methods}

\section{Study area in relation to applications}

The water stood with appropriate depth during the period of July to October when it can be used for various applications. So the 
application period of the waters should be July to October. That is why in November and December sampling were not done from the place of July through October. Rather the other fact was incorporated which is the dynamic relationship existing between monsoon water and the river system in terms of water movement and fisheries. So, in November the water was sampled from the edge of corresponding river-canal and in December, it was sampled directly from the corresponding river-canal. So though one sample was drawn each month, the total number of sampling spots was three. The rectangular box in Figure 1 (Left) includes the locations of these three spots, which is enlarged in Figure 1 (Right) showing the sampling area (rectangular box) and nearby water channels.

\section{Sampling and study parameters}

Sampling was done from the study area once monthly during the period of July 2006 to December 2006. The sampling depth was $15-30 \mathrm{~cm}$. The physical parameters covered transparency, odor, temperature, salinity, electrical conductivity (EC), total suspended solids (TSS), and total dissolved solids (TDS). The chemical parameters of water studied were $\mathrm{pH}$, dissolved oxygen (DO), biochemical oxygen demand $\left(\mathrm{BOD}_{5}\right)$, chemical oxygen demand (COD), hardness (Ca plus $\mathrm{Mg})$, nitrite-nitrogen content $\left(\mathrm{NO}_{2}^{-}-\mathrm{N}\right)$, nitrate-nitrogen content $\left(\mathrm{NO}_{3}^{-}-\mathrm{N}\right)$, Phosphate-phosphorus $\left(\mathrm{PO}_{4}^{3-}-\mathrm{P}\right)$, sulfatesulfur $\left(\mathrm{SO}_{4}^{-}{ }^{-} \mathrm{S}\right)$, chloride (Cl-), sodium $(\mathrm{Na})$,
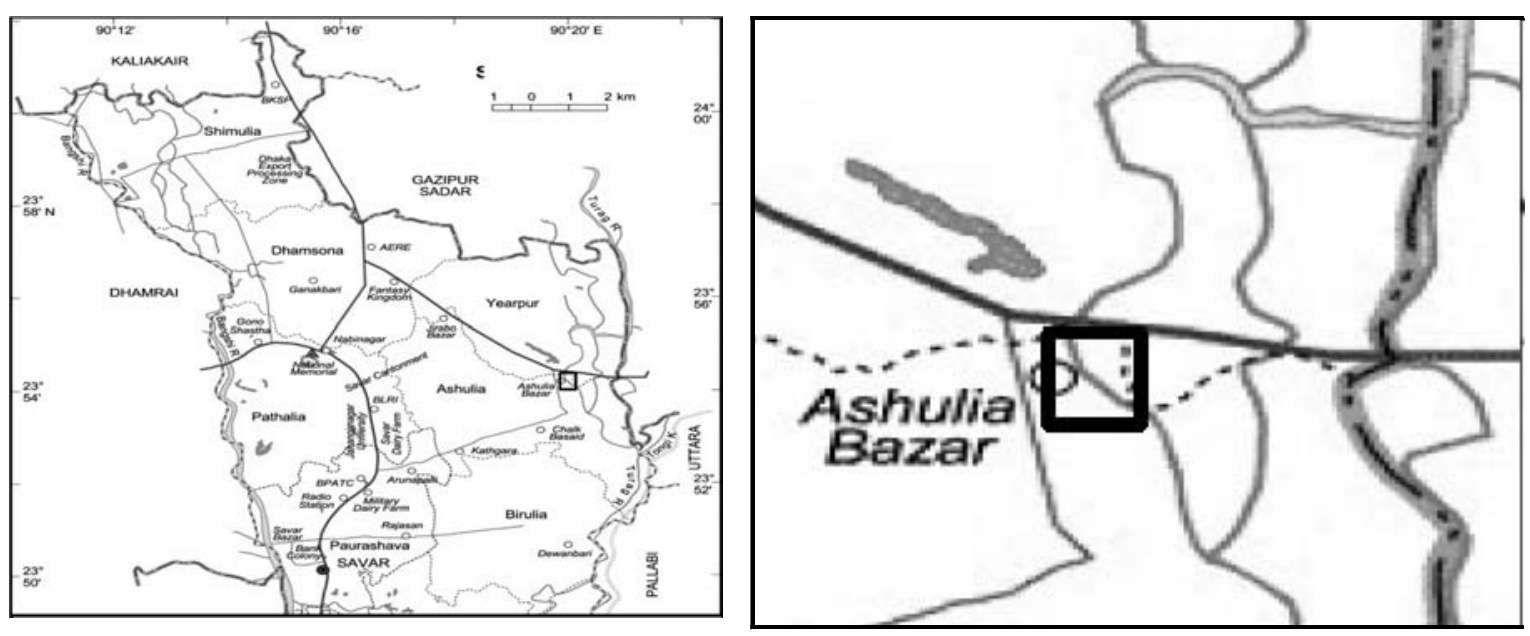

Fig. 1. Left: Map of Ashulia thana with surrounding areas showing the area containing sampling spots in a rectangular box; Right: The sampling area (rectangular box) and nearby water channels, enlarged. 
potassium (K), calcium (Ca), iron (Fe), nickel $(\mathrm{Ni})$, copper $(\mathrm{Cu})$, zinc $(\mathrm{Zn})$, cadmium $(\mathrm{Cd})$, lead $(\mathrm{Pb})$, and mercury (Hg). Among the biological parameters 'phytoplankton' and 'zooplankton' were qualitatively identified in microscopic observation up to genera.

\section{Sample analysis methods}

Among the physical parameters, water transparency and odor were observed with naked eye and nose to examine whether the water is transparent or any bad odor exists. Temperature was measured in the field using degree centigrade thermometer; salinity and electrical conductivity (EC) were measured with digital meters (Salinity Meter: model no. Hanna 8033, EC meter: Bonnet 1, FU 3291, ATC - Conductivity Probe). Total suspended solids (TSS) and total dissolved solids (TDS) were determined by simple laboratory methods.

Among the chemical parameters $\mathrm{pH}$, dissolved oxygen (DO), and biochemical oxygen demand $\left(\mathrm{BOD}_{5}\right.$, incubation of 5 days at $20^{\mathrm{O}} \mathrm{C}$ ) were measured with digital meters (Griffin pH meter, model no. 40; DO meter: Hanna instruments, H19143, Portugal). The chemical oxygen demand (COD) was determined by using method based on chemical oxidation by $\mathrm{Cr}_{2} \mathrm{O}_{7}{ }^{2}$ - in presence of a catalyst in $50 \% \mathrm{H}_{2} \mathrm{SO}_{4}$. Hardness (Ca plus $\mathrm{Mg}$ ) was determined using compleximetric titration by EDTA (Santhanam et al., 1989). The nitrite-nitrogen $\left(\mathrm{NO}_{2}{ }^{-}-\mathrm{N}\right)$, and nitrate-nitrogen $\left(\mathrm{NO}_{3}{ }^{-} \mathrm{N}\right)$ contents were determined col- orimetrically using spectrophotometer (Golterman, et al., 1978; Santhanam et al., 1989). Phosphate-phosphorus $\left(\mathrm{PO}_{4}^{3-}-\mathrm{P}\right)$ was determined by phosphomolybdic blue color method (Dickman and Bray, 1940; Murphy and Riley, 1962; Chattopadhyay, 1998) (5, 6, and 7$)$; and sulfate-sulfur ( $\left.\mathrm{SO}_{4}{ }^{2-}-\mathrm{S}\right)$ was estimated turbidimetrically (Chattopadhyay, 1998). Chloride (Cl-) was determined using titrimetric method (Chattopadhyay, 1998). Sodium ( $\mathrm{Na}$ ) and potassium (K) were determined by flame photometric analysis (Chattopadhyay, 1998). Calcium (Ca), copper $(\mathrm{Cu})$, zinc $(\mathrm{Zn})$, and lead $(\mathrm{Pb})$ were determined by voltametric method and iron $(\mathrm{Fe})$, nickel (Ni), cadmium (Cd), and mercury (Hg) were measured by atomic absorption spectrophotometry (AAS).

The biological parameters such as 'phytoplankton' and 'zooplankton' were qualitatively (up to genera) identified in microscopic observation. Phytoplankton were sampled by preservation and settlement of one liter of each water sample while zooplanktons were sampled by filtering through $55 \mu$ plankton net, and microscopic identifications were performed according to the standard manuals.

\section{Results}

\section{The physical parameters}

Among the physical parameters transparency, odor, temperature, salinity, electrical conductivity, total suspended solids, and total 
dissolved solids were studied with the water samples. The physical parameter studies of the water over the period of July, 2006 to December, 2006 are listed in Table I.
* General chemical properties (Table II): Among the general chemical properties $\mathrm{pH}$, dissolved oxygen, biochemical oxygen demand, chemical oxygen demand, and hardness were studied with the water samples.

Table I. Physical parameters of the water over the study period

\begin{tabular}{|c|c|c|c|c|c|c|}
\hline Months & $\begin{array}{l}\text { July } \\
2006\end{array}$ & $\begin{array}{l}\text { August } \\
2006\end{array}$ & $\begin{array}{c}\text { September } \\
2006\end{array}$ & $\begin{array}{c}\text { October } \\
2006\end{array}$ & $\begin{array}{l}\text { November, } \\
2006\end{array}$ & $\begin{array}{c}\text { December } \\
2006\end{array}$ \\
\hline Transparency & Transparent & Transparent & Transparent & Transparent & Transparent & Translucent \\
\hline Odor & Good & Good & Good & Good & Good & Pungent \\
\hline $\begin{array}{l}\text { Temperature } \\
\left({ }^{\mathrm{O}} \mathrm{C}\right)\end{array}$ & 28.2 & 28.0 & 26.6 & 24.6 & 23.9 & 23.6 \\
\hline $\begin{array}{l}\text { Salinity } \\
\text { (mg/L) }\end{array}$ & 0.83 & 0.64 & 0.58 & 0.70 & 0.93 & 1.50 \\
\hline $\begin{array}{l}\text { Electrical } \\
\text { conductivity, } \\
\text { EC }(\mu \mathrm{mho} / \mathrm{cm})\end{array}$ & 250 & 400 & 513 & 608 & 200 & 128 \\
\hline $\begin{array}{l}\text { Total } \\
\text { suspended } \\
\text { solids, TSS } \\
(\mathrm{mg} / \mathrm{L})\end{array}$ & 0.82 & 0.72 & 0.42 & 0.45 & 0.78 & 0.98 \\
\hline $\begin{array}{l}\text { Total } \\
\text { dissolved } \\
\text { solids, TDS } \\
\text { (mg/L) }\end{array}$ & 5.2 & 4.5 & 2.8 & 3.6 & 7.7 & 9.3 \\
\hline
\end{tabular}

\section{The chemical parameters}

The chemical parameter studies of the water over the period of July, 2006 to December, 2006 are listed in following Tables. The general chemical properties are listed in Table II, the nutrient parameters are listed in Table III, and the heavy metal status is listed in Table IV.
* Nutrient parameters (Table III): Among the nutrient parameters, nitrite - nitrogen, nitrate - nitrogen, phosphate - phosphorus, sulfate - sulfur, chloride, sodium, potassium, calcium, and iron were studied with the water samples. 
Table II. General chemical properties of the water over the study period

\begin{tabular}{l|c|c|c|c|c|c}
\hline \multicolumn{1}{c|}{ Months } & $\begin{array}{c}\text { July } \\
2006\end{array}$ & $\begin{array}{c}\text { August } \\
2006\end{array}$ & $\begin{array}{c}\text { September } \\
2006\end{array}$ & $\begin{array}{c}\text { October } \\
2006\end{array}$ & $\begin{array}{c}\text { November, } \\
2006\end{array}$ & $\begin{array}{c}\text { December } \\
2006\end{array}$ \\
\hline \multicolumn{1}{c|}{$\mathrm{pH}$} & 6.7 & 6.6 & 7.40 & 7.30 & 6.33 & 7.29 \\
\hline $\begin{array}{l}\text { Dissolved oxygen, } \\
\text { DO (mg/L) }\end{array}$ & 6.7 & 6.4 & 6.9 & 6.4 & 6.0 & 6.1 \\
$\begin{array}{l}\text { Biochemical oxygen } \\
\text { demand, BOD }(\mathrm{mg} / \mathrm{L})\end{array}$ & 3.0 & 2.75 & 3.28 & 1.5 & 1.75 & 1.5 \\
$\begin{array}{l}\text { Chemical oxygen } \\
\text { demand, COD (mg/L) }\end{array}$ & 3.04 & 8.35 & 12.89 & 10.91 & 6.02 & 5.52 \\
$\begin{array}{l}\text { Hardness } \\
\text { (Ca plus Mg), (mg/L) }\end{array}$ & 36.5 & 37.5 & 36.08 & 26.08 & 39.31 & 31.0 \\
\hline
\end{tabular}

Table III. Nutrient parameters of the water over the study period

\begin{tabular}{|c|c|c|c|c|c|c|}
\hline Months & $\begin{array}{l}\text { July } \\
2006\end{array}$ & $\begin{array}{c}\text { August } \\
2006\end{array}$ & $\begin{array}{l}\text { September } \\
2006\end{array}$ & $\begin{array}{c}\text { October } \\
2006\end{array}$ & $\begin{array}{c}\text { November, } \\
2006\end{array}$ & $\begin{array}{c}\text { December } \\
2006\end{array}$ \\
\hline $\begin{array}{l}\text { Nitrite-Nitrogen } \\
\left(\mathrm{NO}_{2}^{-}-\mathrm{N}\right),(\mathrm{mg} / \mathrm{L})\end{array}$ & 0.562 & 0.325 & $\begin{array}{c}\text { Not } \\
\text { Detected }\end{array}$ & $\begin{array}{c}\text { Not } \\
\text { Detected }\end{array}$ & 0.794 & 0.696 \\
\hline $\begin{array}{l}\text { Nitrate-Nitrogen }\left(\mathrm{NO}_{3}{ }^{-} \mathrm{N}\right) \text {, } \\
(\mathrm{mg} / \mathrm{L})\end{array}$ & 0.942 & 0.634 & 2.158 & 0.539 & 1.100 & $\begin{array}{c}\text { Not } \\
\text { Detected }\end{array}$ \\
\hline $\begin{array}{l}\text { Phosphate-phosphorus } \\
\left(\mathrm{PO}_{4}^{3-}-\mathrm{P}\right),(\mathrm{mg} / \mathrm{L})\end{array}$ & 2.70 & 2.65 & 2.75 & 2.35 & 2.49 & 2.51 \\
\hline $\begin{array}{l}\text { Sulfate-Sulfur } \\
\left(\mathrm{SO}_{4}^{-2}-\mathrm{S}\right),(\mathrm{mg} / \mathrm{L})\end{array}$ & 0.29 & 0.23 & 0.29 & 0.28 & 0.21 & 0.24 \\
\hline Chloride (Cl-), (mg/L) & 1.65 & 3.02 & 4.60 & 6.16 & 69.43 & 69.95 \\
\hline Sodium (Na), (mg/L) & 3.6 & 5.2 & 7.5 & 12.5 & 20.3 & 17.8 \\
\hline Potassium (K), (mg/L) & 11.2 & 10.1 & 11.5 & 9.7 & 14.2 & 15.1 \\
\hline Calcium (Ca), (mg/L) & 9.02 & 6.52 & 14.82 & 12.90 & 24.25 & 28.05 \\
\hline Iron (Fe), (mg/L) & 0.5062 & 0.3023 & 0.1269 & 0.2465 & 0.4320 & 0.7240 \\
\hline
\end{tabular}

* Heavy metal status (Table IV): To study the heavy metal status, nickel, copper, zinc, cadmium, mercury, and lead were studied with the water samples.

\section{The biological parameters}

In microscopic observation, 'phytoplankton' and 'zooplankton' were qualitatively identi 
Table IV. Heavy metal status of the water over the study period

\begin{tabular}{l|c|c|c|c|c|c}
\hline Months & $\begin{array}{c}\text { July } \\
2006\end{array}$ & $\begin{array}{c}\text { August } \\
2006\end{array}$ & $\begin{array}{c}\text { September } \\
2006\end{array}$ & $\begin{array}{c}\text { October } \\
2006\end{array}$ & $\begin{array}{c}\text { November, } \\
2006\end{array}$ & $\begin{array}{c}\text { December } \\
2006\end{array}$ \\
\hline Nickel $(\mathrm{Ni}),(\mu \mathrm{g} / \mathrm{L})$ & 0.050 & 0.047 & 0.038 & 0.028 & 0.032 & 0.025 \\
Copper $(\mathrm{Cu}),(\mathrm{mg} / \mathrm{L})$ & 0.028 & 0.039 & 0.042 & 0.043 & 0.049 & 0.035 \\
Zinc $(\mathrm{Zn}),(\mu \mathrm{g} / \mathrm{L})$ & 0.048 & 0.023 & 0.039 & 0.047 & 0.038 & 0.036 \\
Cadmium $(\mathrm{Cd}),(\mu \mathrm{g} / \mathrm{L})$ & 0.0029 & 0.0043 & 0.0023 & 0.0024 & 0.0043 & 0.0028 \\
Mercury $(\mathrm{Hg})$, & Not & Not & Not & Not & Not & Not \\
$(\mu \mathrm{g} / \mathrm{L})$ & Detected & Detected & Detected & Detected & Detected & Detected \\
Lead $(\mathrm{Pb}),(\mu \mathrm{g} / \mathrm{L})$ & 0.050 & 0.043 & 0.093 & 0.060 & 0.072 & 0.038 \\
\hline
\end{tabular}

fied up to genera. The identified phytoplankton and zooplanktons are listed in Table V and Table VI, respectively.

Table V. Identified phytoplankton in the water over the study period

\begin{tabular}{|l|c|c|}
\hline Class & Order & Genus \\
\hline Bacillariophyceae & Centrales & Melosira \\
\cline { 3 - 3 } & Pennales & Cymbella \\
\cline { 3 - 3 } & & Fragilaria \\
\cline { 3 - 3 } & & Gomphonema \\
\cline { 3 - 3 } & & Navicula \\
\cline { 3 - 3 } & & Pinnularia \\
\cline { 3 - 3 } & & Synedra \\
\hline Chlorophyceae & Chlorococcales & Chlorella \\
\cline { 3 - 3 } & Conjugales & Closterium \\
\cline { 3 - 3 } & & Cosmarium \\
\hline \multirow{3}{*}{ Euglenophyceae } & Volvocales & Chlamydomonas \\
\hline Cyanophyceae & Ehronales & Euglena \\
\hline & & Merismopedia \\
\cline { 3 - 3 } & Nostocales & Anabaena \\
\cline { 3 - 3 } & & Nostoc \\
\cline { 3 - 3 } & & Oscillatoria \\
\hline
\end{tabular}

Table VI. Identified zooplanktons in the water over the study period

\begin{tabular}{|c|c|c|c|}
\hline Phylum & Class & Order & Genus \\
\hline \multirow{6}{*}{ Arthropoda } & \multirow{6}{*}{ Crustacea } & \multirow{4}{*}{ Cladocera } & Bosmina \\
\hline & & & Daphnia \\
\hline & & & Diaphanosoma \\
\hline & & & Moina \\
\hline & & \multirow[t]{2}{*}{ Copepoda } & Cyclops \\
\hline & & & Diaptomus \\
\hline
\end{tabular}

\section{Discussion}

\section{The physical parameters:}

Fresh water can be defined as water with less than 0.5 parts per thousand dissolved salts (The Groundwater Foundation, 2007). Wilkipedia classified water into four classes according to salinity - fresh water $(<0.5$ ppt), brackich water (0.5-35 ppt), saline water (35-50 ppt), and brine (> $50 \mathrm{ppt}$ ) (Wilkipedia, 2007). Freshwater bodies include lakes, rivers, openwaters, and some bodies of underground water. The ultimate 
source of fresh water is the precipitation of atmosphere in the form of rain and snow. The salinity of the water samples produced a maximum value of 1.50 parts per million which is very much low in comparison with the maximum value for freshwaters. So the water is very suitable for the freshwater organisms having sensitivity for salinity. The salinity values showed a regular decrease from July to September, and again regular increase from October to December. This indicates dilution due to usual increase in water during the first three months and decrease in the last three months having direct connection with river-canals.

Figure 2. Salinity of the water samples

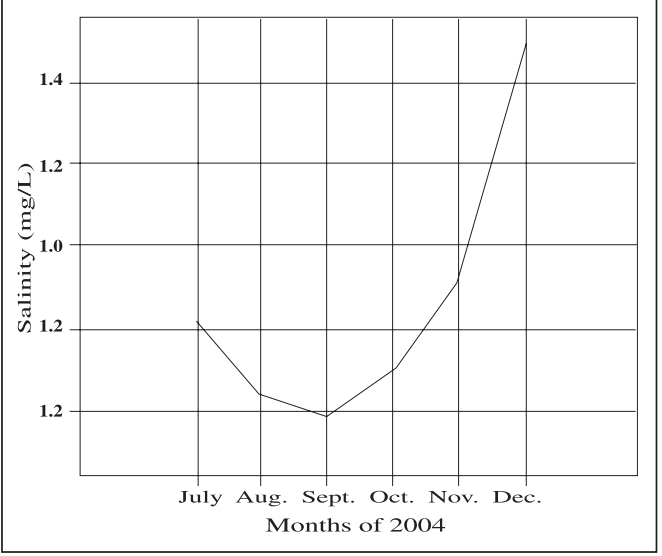

Fig. 2. Trend in salinity of the water samples during the study period

During July to November the water was tranparent, but in December it turned translucent. Transparency is inversely proportional to turbidity which in turn proportional to the amount of suspended organic and inorganic matters. So during the application period (July through October) light can penetrate well through the water and the growth of phytopolankton would be good. The odor of the water was good during July to November, but it turned to give pungent odor after November.

Different species of fish, especially the larvae, have sensitive temperature requirements. Even for the different stages of growth for same species, the temperature requirements vary. Temperature controls the maximum rate at which chemical reactions can occur. Changes in temperature will have direct effects on all aspects of the metabolism of fishes unless mechanisms for evading these pervasive effects have evolved (Brett and Groves, 1979; Graham, 1983). For freshwater prawn, the optimum temperature range is $26{ }^{\circ} \mathrm{C}-31{ }^{\circ} \mathrm{C}$ and within this range larvae grow and molt more quickly as temperature increases, while temperatures over $33{ }^{\circ} \mathrm{C}$ are normally lethal (New and Singholka, 1985). The temperature of the water samples descended from $28.2^{\circ} \mathrm{C}$ to $23.6{ }^{\circ} \mathrm{C}$ from July to December due to seasonal variation. But in regard to the application period (July through October) the temperatures were $28.2^{\circ} \mathrm{C}, 28.0{ }^{\circ} \mathrm{C}, 26.6{ }^{\circ} \mathrm{C}$, and $24.6{ }^{\circ} \mathrm{C}$. As lower temperature prevailed at the end of the period, the time portion to be used for prawn larvae conforms to the standard requirement. The temperature range is also suitable for recreational purposes. 


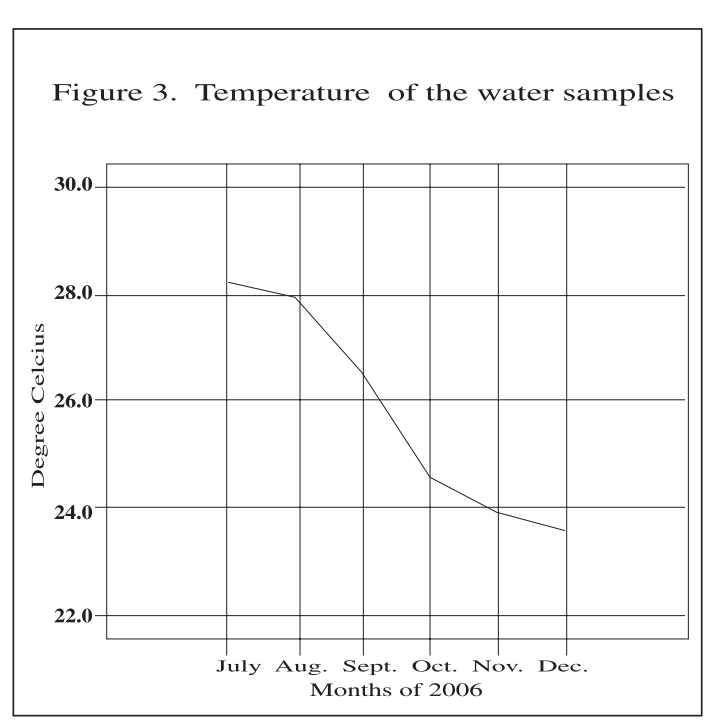

Fig. 3. Temperature trend of the water samples during the study period

The electrical conductivity indicates the total concentration of ionized constituents of water. It is closely related to the amount of total dissolved solids and is also an index of salt content of water. EC values are closely related with temperature. EC of a solution increases approximately at the rate of $2 \%$ per ${ }^{\circ} \mathrm{C}$ (Chattopadhyay, 1998). Freshwaters, in general, exhibit low EC values expressed as $\mu \mathrm{mhos} / \mathrm{cm}$ instead of $\mathrm{m}$ mhos/cm. Boyd stated natural waters usually have EC values of 20 to $1500 \mu \mathrm{mhos} / \mathrm{cm}$ (Boyd, 1978). The EC values of the samples increased from 250 to 608 , and then decreased again to $128 \mu$ mhos/cm. So the EC values of the water samples can be considered very suitable.

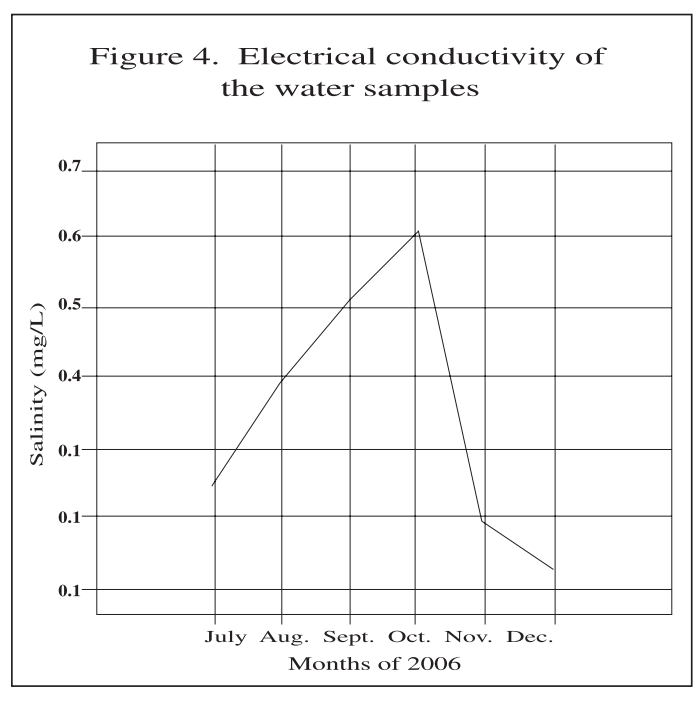

Fig. 4. Trend in electrical conductivity of the water samples during the study period

Suspended solids are not good for fish culture for a number of reasons. They reduce the amount of light that can enter the water and so reduce rates of photosynthesis and productivity. They damage fish gills, reduce visibility, can be very bad for zooplankton, and also adsorb nutrients added to ponds preventing phytoplankton from using those (STOAS, 1997). The highest TSS concentration for the water samples was $0.98 \mathrm{mg} / \mathrm{L}$ which is very dilute to produce the adverse effects. Total dissolved solids represent dissolved organic matters, particulate organic matters, and dissolved inorganic substances excepting gases. The essential nutrient pool dissolved in water mainly constitutes the TDS. But too high concentration can lead to very faster eutrophication of water body and thereby making it unsuitable for fish culture. 
The TSS and TDS values of the water samples decreased in first three months and subsequent increase was observed in the last three months which indicates dilution due to usual increase in water during the first three months and decrease in the rest months having direct connection with river-canals. But the TDS was manifold higher than the corresponding TSS values which is a good characteristic of the water studied.

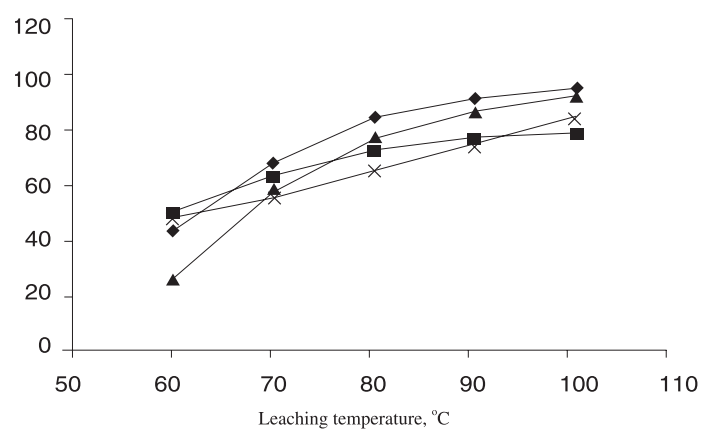

Fig. 5. Comparison berween TDS and TSS values of the water samples during the study period

\section{The chemical parameters}

Most cultured species of fish prefer a $\mathrm{pH}$ range of 6.5 to 9 (STOAS, 1997). Large changes in $\mathrm{pH}$ tend to stress fish and reduce growth. As per STOAS $\mathrm{pH}$ values 4 or less and 12 or high cause death to most of the fish species, 6 to 8 is the range for good growth and reproduction, and $\mathrm{pH}$ as low as 5 or as high as 9 to 11 do not allow fishes to reproduce and cause slow growth (STOAS, 1997). The $\mathrm{pH}$ range of water samples during the application period (July through December) was within 6.6 to 7.3 which are well inside of the appropriate $\mathrm{pH}$ range for most of the fish species.

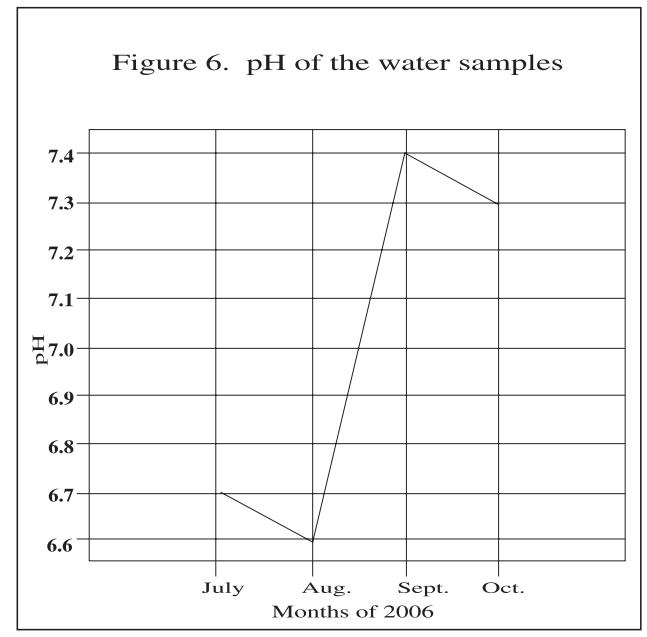

Fig. 6. Trend in $\mathrm{pH}$ of the water samples during the application period

Solubility of oxygen is affected nonlinearly by temperature, and increases considerably in cold water. Oxygen solubility declines exponentially with increases in salt content, and is reduced by about $20 \%$ in normal sea water as compared to the amount in fresh water (Wetzel, 1983). The general relation- 
ship of oxygen solubility as a function of temperature was shown by Benson and Krause (1980). In the relationship temperatures $20,25,30,35$, and $40^{\circ} \mathrm{C}$ were shown to have corresponding oxygen solubility of 9.092, 8.263, 7.558, 6.949, and 6.421 mg/L, respectively. With the conjoint function of other factors involved in solibility, the observed temperature range during the application period (24.6 - 28.2 ${ }^{\mathrm{O}} \mathrm{C}$ ) produced maximum DO value of $6.9 \mathrm{mg} / \mathrm{L}$ and a minimum of $6.4 \mathrm{mg} / \mathrm{L}$ which are well above the minimum value of $4.5 \mathrm{mg} / \mathrm{L}$ (STOAS, 1997) for good fish growth and health, and feed conservation in the water body.

As a fish increases in size, its demand for oxygen also increases. But the rate of respiration is not directly proportional (isometric) to body weight, rather the rate of oxygen consumption per unit mass decreases as fishes get heavier (Wootton, 1992). High biochemical oxygen demand reduces the amount of oxygen available to fish and stimulates anaerobic conditions. Anaerobic environments stimulate the formation of toxic gases such as hydrogen sulfide and ammonia, which severely affect the functioning of the gills. The most critical time for oxygen depletion is at night when phytoplankton is not photosynthesizing and just before dawn when the fish may be seen gulping air at the surface. Chattopadhyay, et al. suggested 10 to $20 \mathrm{mg} / \mathrm{L} \mathrm{BOD}_{5}$ load of pond water to be optimum for aquaculture (Chattopadhyay, et al. 1988). $\mathrm{BOD}_{5}$ in the water samples were within the range of 1.5 and 3.28, which are low than the optimum indicating low presence of organic matter decomposable by microorganisms in the water. But the water under study is not pond water rather it is open freshwater, and the values are not too low to consider the water substratum-deficient for microorganisms. Like BOD, COD (chemical oxygen demand) is also an index of the organic enrichment of water and the optimum range of COD for fish ponds may be considered to be between 80 and 100 $\mathrm{mg} / \mathrm{L}$. But the water under study produced 3.02 to $12.89 \mathrm{mg} / \mathrm{L}$ COD at different times which is much low than the optimum requirement for fish pond. But the important fact is, the BOD and COD values are not at that high which reduces the amount of oxygen available to fish and renders the water body unsuitable for fishery.

The hardness of water is governed by the content of calcium and magnesium salts, largely combined with bicarbonate and carbonate (temporary hardness) and with sulfates, chlorides, and other anions of mineral acids (permanent hardness) (Wetzel, 1983). Magnesium compounds are much more soluble than their calcium counterparts. The monocarbonates of hard waters are usually 
more than $95 \% \mathrm{CaCO}_{3}$ under ordinary $\mathrm{CO}_{2}$ pressures, and $\mathrm{MgCO}_{3}$ and $\mathrm{Mg}(\mathrm{OH})_{2}$ precipitate significantly only at very high $\mathrm{pH}$ values (>10) under most natural conditions (Wetzel, 1983). Hardness is often equal to alkalinity and it is important in fish ponds for exactly the same reason as for alkalinity. Ponds with low alkalinity (20 mg/L) are not productive and have water that may change $\mathrm{pH}$ rapidly. Soft waters as well as the waters of low alkalinity should be limed to be productive. The water samples contained a minimum of 26.08 to maximum $37.5 \mathrm{mg} / \mathrm{L}$ hardness during the application period which clearly indicates the suitability of the water for fishery.

$\mathrm{NO}_{2}{ }^{-}-\mathrm{N}$ levels of natural lake waters are generally very low, in the range of 0 to 0.01 $\mathrm{mg} / \mathrm{L}$, although concentrations of up to 1 $\mathrm{mg} / \mathrm{L}$ have been found in the interstitial waters of deep (>90 cm depth) sediments (Konrad, et al. 1970). Concentrations of $\mathrm{NO}_{2}{ }^{-} \mathrm{N}$ increase in the anaerobic hypolimnion of lakes under reducing conditions (Brezonik and Lee, 1968) and in streams and lakes receiving heavy organicmatter pollution. The water samples contained $\mathrm{NO}_{2}{ }^{-}-\mathrm{N}$ from undetectable to a maximum of $0.562 \mathrm{mg} / \mathrm{L}$ during the application period which indicates good natural condition of the water. Concentration of $\mathrm{NO}_{3}{ }^{-}-\mathrm{N}$ range from undetectable levels to nearly 10 $\mathrm{mg} / \mathrm{L}$ in unpolluted fresh waters, but are highly variable seasonally and spatially (Wetzel, 1983)15. The water samples contained $\mathrm{NO}_{3}{ }^{-}-\mathrm{N}$ from 0.539 to $2.158 \mathrm{mg} / \mathrm{L}$ during the application period which also refers to a good natural condition of the water.

Compounds containing phosphorus play major roles in nearly all phases of metabolism, particularly in the energy transformation of phosphorylation reactions during photosynthesis. Phosphorus is required in the synthesis of nucleotides, phospholipids, sugar phosphates, and other phosphorylated intermediate compounds. Further, phosphate is bonded, usually as an ester, in a number of low-molecular-weight enzymes and vitamins essential to algal metabolism (Wetzel, 1983). The most important form of phosphorus for plant nutrition is ionized inorganic phosphate. Extensive investigations of minimal and maximal phosphorus concentrations, especially by Chu and Rodhe, grouped freshwater algae into categories according to whether their tolerance ranges fell below, around, or above $20 \mu \mathrm{g} \mathrm{PO}_{4}^{3-}$-P per liter (Chu, 1943 and Rodhe, 1948). The water samples contained 2.35 to $2.75 \mathrm{mg} \mathrm{PO}_{4}^{3-}-\mathrm{P}$ per liter, which according to the categories supports optimal growth of green algae such as Scenedesmus, Ankistrodesmus, and many others. 
Sulfur is utilized by all living organisms in both inorganic and organic forms. Sulfate is reduced to sulfhydril (-SH) groups in protein synthesis, with a concomitant production of oxygen that is utilized in oxidative metabolic reactions. Decomposition of organic matter containing proteinaceous sulfur and the anaerobic reduction of sulfate in stratified waters both contribute to altered conditions that markedly affect the cycling of other nutrients, ecosystem productivity, and distribution of the biota. The usual optimal range of sulfate in natural waters is about 5 to 30 $\mathrm{mg} / \mathrm{L}$, with an average of about $11 \mathrm{mg} \mathrm{SO}_{4}{ }^{2-}$ per liter (Wetzel, 1983). If $\mathrm{SO}_{4}^{3-}$ is converted to sulfur, the range becomes about 1.67 to 10 $\mathrm{mg} / \mathrm{L}$ with an average of about $3.67 \mathrm{mg} / \mathrm{L}$. The water samples contained 0.21 to 0.29 $\mathrm{mg} \mathrm{SO}_{4}{ }^{2-}-\mathrm{S}$ per liter which is quite low. So the water does not contain sufficient sulfur to support phytoplankton, which should be managed while using the water for fishery.

Chloride is influential in general osmotic salinity balance and ion exchange, but metabolic utilization does not cause significant variations in the special and seasonal distribution within a lake (Wetzel, 1983). Usually chloride is not dominant in open water systems. The water samples contained 1.65 to $6.16 \mathrm{mg} / \mathrm{L}$ chloride during the application period.
The monovalent cations sodium and potassium are involved primarily in ion transport and exchange. Both sodium and potassium occur in such abundance as highly soluble cations of numerous salts that alteration of their concentrations in content of natural waters is not common (Wetzel, 1983). An absolute sodium requirement has been demonstrated in only a few plants. The sodium requirements are particularly high in some species of blue-green algae (Allen, 1952). A threshold level of $4 \mathrm{mg} \mathrm{Na} / \mathrm{L}$ is required for near optimal growth of several species (Kratz and Myers, 1955). Moderate epilimnetic reduction in potassium concentration, which has been observed in extremely productive lakes, is presumably related to potassium utilization by the massive algal populations and by submerged macrophytes (Mickle and Wetzel, 1978). The water samples have shown presence of more sodium than the requirement for almost all of the period (3.6 to $12.5 \mathrm{mg} / \mathrm{L}$ during the application period). So sodium is obviously present at adequate levels throughout the period to support growth of phytoplankton. Potassium is also present in the water samples within 9.7 to $11.5 \mathrm{mg} / \mathrm{L}$ during the application period.

Calcium has been implicated in numerous ways in the growth and population dynamics of freshwater flora and fauna. A universal 
requirement for calcium has not been demonstrated for algae, but most likely it is required by the green algae, and is considered as essential inorganic element of algae. Wherever essential, calcium is usually needed as a micronutrient (Wetzel, 1983). Various species have different sensitivity for calcium. Species of the larger genera are divisible into those adapted to acidic $(\mathrm{pH}<6)$, calcium deficient waters ( $<10 \mathrm{mg} \mathrm{Ca} / \mathrm{L}$ ), through a series of those adapted to increasingly alkaline, calcium-rich waters (Hutchinson, 1967). Over the application period, calcium was present within 6.52 to $14.82 \mathrm{mg} / \mathrm{L}$ in the water samples.

For the growth of algae the essentiality of iron as micronutrient is established (Wetzel, 1983). Iron was present in the water samples within 0.1269 to $0.5062 \mathrm{mg} / \mathrm{L}$ in the water samples.

Among the analyzed heavy metals after iron, copper and zinc are micronutrients. It is important to note that the relative concentrations of trace elements in fresh waters can have a significant effect on the competitive abilities of species in algal communities. Most metallic micronutrients are very toxic when in excess or when complexed organically to the point when their availability exceeds tolerance limits (Wetzel, 1983). The average concentration of both copper and zinc in world surface lakes and rivers is 10 $\mu \mathrm{g} / \mathrm{L}$ (Livingstone, 1963). In the water samples during the application period copper was present within 28 to $49 \mu \mathrm{g} / \mathrm{L}$, while zinc was present within 0.023 to $0.048 \mu \mathrm{g} / \mathrm{L}$. So the values of copper are a bit higher than that of world's average concentration, but zinc is well below than the value. Among nickel, cadmium, mercury, and lead, mercury was not detected at ppb level in any of the water samples. Nickel was present within 0.025 to $0.050 \mu \mathrm{g} / \mathrm{L}$, while cadmium and lead ranged within 0.0023 to $0.0043 \mu \mathrm{g} / \mathrm{L}$ and 0.038 to $0.093 \mu \mathrm{g} / \mathrm{L}$, respectively. These observed values of nickel, cadmium, and lead are so low that the water can easily be considered safe for fishery and recreational applications.

\section{The biological parameters}

Phytoplankton are the autotrophic prokaryotic or eukaryotic algae that live near the water surface where there is sufficient light to support photosynthesis. Through photosynthesis, phytoplankton are responsible for much of the oxygen present (up to 60\%) in the Earth's atmosphere. Their cumulative energy fixation in carbon compounds (primary production) is the basis for the vast majority of oceanic and also many freshwater food webs (chemosynthesis is a notable exception). Most phytoplanktonic organisms are motile, possess some structural feature, or contain 
oil droplets which give them buoyancy; all these features aid the organisms in maintaining their location in the photosynthetic zone. Otherwise, the phytoploanktons are usually denser than water, and constantly sink by gravity to lower depths.

The zooplanktons include animals suspended in water with limited powers of locomotion. Freshwater zooplanktons are dominated by four major groups of animals: protozoa, rotifers, and two orders of the Crustacea, the cladocerans and copepods. The planktonic protozoa have limited locomotion, but the rotifers, cladoceran and copepod microcrustaceans often move extensively in quiescent water. Zooplankton are initially the sole prey item for almost all fish larvae as they use up their yolk sacs and switch to external feeding for nutrition. Fish species rely on the density and distribution of zooplankton to coincide with first-feeding larvae for good survival of larvae, which can otherwise starve.

Phytoplanktons as identified in the waters use up some of the nutrients but they themselves serve as food for zooplankton and fishes. As fishes consume phytoplankton and zooplankton, the immobilized nutrients in the planktons become available for fishes. The identified pool of phytoplankton comprises species from diverse classes which clearly indicates richness of the water from ecosystem's point of view to supply specific requirements for each of diverse types of producers. The zooplanktons comprised relatively large size classes - the cladocerans and copepods, which indicates fish scarcity in the water than could be supported; and selective predation of smaller zooplanktons by larger ones.

\section{Relationship between monsoon water and the} river system for fisheries

During the wet season, the floodplain environment offers a dramatically increased living space and availability of resources. Changes in hydrology are probably important stimuli to life-cycles (Payne, 1986). Dissolved oxygen concentrations are particularly important in determining the distribution of fishes. For a majority of fish species, rising water levels within the main channel are associated with upstream migrations towards the floodplain area in order to avoid unfavorable conditions and/or to exploit more favorable ones. Most spawning activity of migratory species occurs during the flood season (Payne, 1997).

During high water, the flooded land yields a rich and varied food supply. For all fishes, this is a period of great abundance of food and of growth. The development of young fishes is extremely rapid and eggs tend to hatch relatively quickly (several hours and 
days) - for example, the eggs of major carps in the rivers of Southern Asia tend to hatch within around 16 hours. Many species cease to feed during the dry season and rates of growth are often lowered or may be halted. At the end of the rains, as the expanse of floodwater retreats and contracts and the supply of resources diminishes, falling water levels promote return migrations as large numbers of fish retreat back into the main river channel. The dry season then is a period of high predator pressure from birds, predatory fish, and, of course, from fishermen (Payne, 1997).

\section{Openwater fishes}

With the aim of proper utilization of these waterbodies to augment fish production, researches have been conducted since early 1950s, but have gained remarkable momentum in the last two decades. It is since early 1990s that a concerted research program has been undertaken on the floodplains of the country, when the fish production has been alarmingly low. In the early 1960s the floodplain contributed about $90 \%$ of the total fish production. In recent years the production has dropped down to $50-55 \%$ due to manmade alterations in fish habitats caused by flood protection measures, overfishing, irrigation, and improper use of insecticides/herbicides. Among the species of fish contribut- ing to floodplain fish production, it is probably the Indian major carps that have been declined alarmingly from about $30 \%$ in the 1960 s to $5 \%$ in recent years. The way this group of fish contributed to the production is unique. During the early monsoon, members of this group (Catla catla, Labeo rohita, Cirrhinus mrigala, Labeo calbasu) spawn in certain parts of few rivers of the country. With the progress of the monsoon, river water containing major carp larvae entered into floodplains for 5-6 months of their life. Other groups of fishes namely murrels, catfishes, perch, loach, feather backs, prawn, minor carp, etc spawn in floodplains/rivers and grow in floodplains (Paule and Mazid, 1997).

In some experiments during 1985-86, prawn (Macrobrachium rosenbergii) seeds were stocked in two experimental ponds and after 3 months a partial harvest showed their average weight to be $134 \mathrm{~g}$ in one pond and 100 $\mathrm{g}$ in the other. The prawn harvest (partial) was computed at $31.2 \mathrm{Kg}$ per acre (77 Kg per ha) in one pond, and 21.7 Kg per acre (53.7 Kg per ha) in the other (Ameen, 1987).

The monsoon water of Ashulia, could be managed for possible hatchery activities or growing various fish species in either cage or pen cultural methods. A cage is a floating structure enclosed usually in netting; and a 
pen is an area of a larger water body, such as a reservoir or lake, which is separated off by the use of netting, bamboo, or other structure. Small scale cage and pen experiments have taken place in Thailand and initial results with pen culture have encouraged the Asian Development Bank to support the extension of this technique there (International Agro-Fisheries System, 1978).

\section{Relationship with soils and aquatic weeds}

The soil analysis was not done and correlated with the water parameters since the main waters of interest are completely out of the river canals and they do not stay throughout the year except the monsoon period. During the other seasons the lands remain dry and are used either for agriculture or as pasture. So when the waters come by both surface runoff of rain water and the overflow of river channels, grasses and crop residues decompose anaerobically and supply mineralized nutrients to the nutrient pool of waters. The surface runoff and river flow contribute greatly to the enrichment of waters with nutrients and planktons. Again as almost no aquatic weed can grow in the main water, so there will be no competition between the planktons and the weeds for nutrient requirements.

\section{Aesthetic applications of Ashulia waters}

The vastness and calmness of water is itself a beauty. Recreational use of water varies from active sports to the simple pleasure of walking, watching and listening to water. Due to the natural beauty, monsoon waters of Ashulia have recently been a recreational site for Dhaka city people and neighboring areas. Many people take an opportunity of spending a weekend evening by these waters. Again, at recent times some parks and recreational infra-structures have been established in the nearby areas. With an integrated approach these can be turned to a good tourism interest which eventually can be regarded economic application as well.

\section{Conclusion}

Almost all of the physical, chemical, and biological parameters of the monsoon water of Ashulia are appropriate as well as safe for economic applications such as various types of fishery as well as enhancing the present recreational applications. In the fishing approach these waters can be managed in three ways:

* Can be used for possible hatchery activities,

* Growing various fish species in either cage or pen cultural methods, or 
* In an integrated approach with the river, the waters can be managed to provide fishery of 'Turag' river a period of great abundance of food and of growth for their life cycle, and thereby restoring natural fish resources of river which is of great economic and ecosystem importance.

Again in the aesthetic approach these waters can be managed to enhance the natural beauty and thereby using for recreational purposes as well as in an integrated approach with the existing recreational infra-structures these waters can be turned to a good tourism interest.

\section{References}

Allen, M.B. (1952) The cultivation of Myxophyceae. Arch. Mikrobiol. 17: 34-53.

Ameen, Mahmud-ul. 1987. Fisheries Resources and Opportunities in Freshwater Fish Culture in Bangladesh. Pat, NRD-II/DANIDA.

BBS. 2003. (2001) Statistical Yearbook of Bangladesh, 22/e. Bangladesh Bureau of Statistics, Planning Division, Ministry of Planning, Government of Peoples Republic of Bangladesh.

Benson, B. B., and D. Krause, Jr. (1980) The concentration and isotopic fractionation of gases dissolved in freshwater in equilibrium with the atmosphere. 1. Oxygen. Limnol. Oceanogr. 25: 662-671.

Boyd, C. E. (1978) Water Quality in Warmwater Fish Ponds. Agril. Expt. Stn. Auburn Univ.

Brett, J.R., and T.D.D. Groves. (1979) Physiological energetics. pp. 279-352. In W. S. Hoar, D. J. Randall, and J. R. Brett (ed.) Fish Physiology, Vol. VIII. Academic Press, London.

Brezonik, P.L., and G.F. Lee. (1968) Denitrification as a nitrogen sink in Lake Mendota, Wisconsin. Environ. Sci. Technol. 2: 120-125.

Chattopadhyay, G.N, P.K. Saha, A. Ghosh and H.C. Karmakar. (1988) A study on optimum BOD levels for fish culture in wastewater ponds. Biol. Wastes. 25: 79-83.

Chattopadhyay, G.N. (1998) Chemical Analysis of Fish Pond Soil and Water. Daya Publishing House, Delhi - 110035.

Chu, S.P. (1943) The influence of the mineral composition of the medium on the growth of planktonic algae. II. The influence of the concentration of inorganic nitrogen and phosphate phosphorus. J. Ecol. 31: 109148.

Dickman, S.R and R.H. Bray (1940) Colorimetric determination of phosphate. Ind. Eng. Chem. Anal. 12: 665-668. 
Experimental studies in the ecology of phytoplankton. Symbol. Bot. Upsalien. 10(1) 149 pp.

Golterman, H.L., R.S. Clymo, and M.A. M. Ohnstad. (1978). Methods for Physical and Chemical Analysis of Freshwaters, 2/e. Blackwell Scientific Publications, London.

Graham, J.B. (1983) Heat transfer. pp. 248-279. In P. W. Webb, and D. Weihs (ed.) Fish Biomechanics. Praeger, New York.

Hutchinson, G.E. (1967) A Treatise on Limnology. II. Introduction to Lake Biology and the Limnoplankton. New York, John Wiley and Sons, Inc.

International Agro-Fisheries System. (1978) Inland fisheries development project of the Kingdom of Thailand, Final report, Volume 2. Manila, Philippines, Asian Development Bank.

Konrad, J.G., D.R. Keeney, G. Chesters, and K. L. Chen. (1970) Nitrogen and carbon distribution in sediment cores of selected Wisconsin lakes. J. Water Poll. Control Fed. 42: 2094-2101.

Kratz, W. A. and J. Myers. (1955) Nutrition and growth of several blue-green algae. Amer. J. Bot. 42: 282-287.

Livingstone, D.A. (1963) Chemical composition of rivers and lakes. Chap. G. Data of
Geochemistry. 6th ed. Prof. Pap. U.S. Geol. Surv. 440-G, 64 pp.

Mickle, A.M., and R.G. Wetzel. (1978) Effectiveness of submerged angiospermepiphyte complexes on exchange of nutrients and organic carbon in littoral systems. I. Inorganic nutrients. Aquatic Bot. 4: 303316.

Murphy, J. and J.P. Riley. (1962) A modified single solution method for the determination of phosphate in natural waters. Analytica Chim. Acta. 27: 31.

New, M.B. and Singholka, S. (1985) Freshwater Prawn Farming. Daya Publishing House, Delhi - 110035.

Paule, S. K., and M. A. Mazid. (1997) Limnology of some floodplains of Bangladesh. pp. 125-136. In Chu-fa Tsai and M. Youssouf Ali (ed.) Openwater Fisheries of Bangladesh. The University Press Limited, Bangladesh.

Payne, A. (1997) Tropical floodplain fisheries. pp. 1-26. In Chu-fa Tsai and M. Youssouf Ali (ed.) Openwater Fisheries of Bangladesh. The University Press Limited, Bangladesh.

Payne, A.I. (1986) The Ecology of Tropical Lakes and Rivers. John 
Rodhe, W. (1948) Environmental requirements of freshwater plankton algae. Experimental studies in the ecology of phytoplankton. Symbol. Bot. Upsalien. 10(1) :149 p.

Santhanam, R.P. Velayutham, and G. Jegatheesan. (1989) A Manual of Freshwater Ecology. Daya Publishing House, Delhi - 110006.

Soil Resource Development Institute, Ministry of Agriculture, the Govt. of People's Republic of Bangladesh. (1992) Land and Soil Resource Utilization Guide, Savar thana, Dhaka District.

STOAS. (1997) Fish Farming in Tropical Fresh Water Ponds. Foundation for the Development of Agricultural Education and Training, Wageningen, the Netherlands.
The Groundwater Foundation. (2007)

Wetzel, R.G. (1983) Limnology, 2/e. Saunders College Publishing; Holt, Rinehart \& Winston, Inc.

Wilkipedia. (2007)

Wootton, R.J. (1992) Fish Ecology. Blackie Academic and Professional, London.

Received : August 16, 2007;

Accepted : October 29, 2007 